DOI 10.18551/rjoas.2020-03.04

\title{
ADVERTISING VALUE OF INSTAGRAM STORIES AND THE EFFECT ON MILLENNIAL'S ATTITUDE
}

\author{
Mahatmavidya Putu Arya*, Student \\ Study Program of Management, University of Udayana, Denpasar, Indonesia \\ Yasa Ni Nyoman Kerti, Professor \\ Faculty of Economics and Business, University of Udayana, Denpasar, Indonesia \\ *E-mail: aryamahatmavidya@gmail.com
}

\begin{abstract}
This study begins to measure millennial consumer's attitude of Instagram Stories ads on a sample of Denpasar \& Badung Millennials. Collecting the data was using an online survey among 100 millennials. Hypothesizes were the antecedents on advertising value, which were informativeness, entertainment, irritation and credibility; the advertising value; and the last was the attitude towards the Instagram stories ads. The research model was estimated using Partial Least Squares. Results show Credibility and Entertainment were the strongest predictors, with Informativeness in third place. The irritation has a significant negative effect to the advertising value. This indicates the advertiser should create a credible and enjoyable visual to targeting the millennial. Millennials tend to ignore traditional advertising formats. Meanwhile, they are heavy users of Social Networking Sites, especially Instagram. This research presents the first empirical estimation of the Ducoffe model of Advertising Value in the Instagram stories, and the sample is Millenials in Denpasar and Badung (Indonesia). Our research results have relevant implications for brands targeting Millennials through Instagram stories ads.
\end{abstract}

\section{KEY WORDS}

Advertising value, attitude towards advertising, Instagram ads, social media ads.

The rapid growth of information and communication technology can support the expanse of social media sites and applications in the last decade (El-Haddadeh et al., 2012). Raacke and Bonds (2008) state that there are two main reasons people use social media, namely for their social connections (staying in touch with family, friends, and business partners) and sharing information (an entertainment event or talking about something). Previous studies have also shown that entertainment is content that is often consumed and shared on a social media site (LaRose et al., 2001)

Instagram, as one of the social media platforms most often used by millennials, announced that their users are growing, and in June 2018, it was stated that their active users in a month reached 1 billion users. Indonesia is a country that contributes a lot of users to social media, especially Instagram. Based on data from Statista, in January 2020, Indonesia has 63 million active Instagram users in a month. Indonesia is the 4th largest country for Instagram users under the United States, India, and Brazil, with 63 million monthly users.

Instagram is a social media that can be used to advertise. There are five types of Instagram ads that can be used by a business, namely photo ads, video ads, carousel ads, Instagram stories ads, and collection adverts ads (Instagram website, 2019). Instagram stories are a feature that is developing very fast, which is currently used by 500 million accounts per day (Instagram website, 2019). Business people have the opportunity to exploit the potential of Instagram stories to connect with customers where the customer is active. $52 \%$ of Indonesians become more interested in a product or brand after seeing it on Instagram stories (Facebook, 2018). Through advertisements on Instagram Stories, business 
people can promote products, build brand awareness, and drive sales in a way that suits their customers' browsing experience (Instagram website, 2019).

Businesses have begun to see the results of using advertisements on Instagram Stories. For example, Tropicana ran video advertisements on Instagram Stories for their summer product promotion campaign and was able to produce an 18 point increase in ad recall. Another example is that Samsung is targeting Instagram stories widely to Indonesians aged 18 and over so that there are as many users as possible who can find its products. This compelling story format can reach $65 \%$ of the company's target audience, increase ad recall by 9 points, and brand preferences by 7 points. Also, the Italian snack company Pan in Stelle uses Instagram stories advertisements for their cake product campaign targeting the millennial generation. Pan di Stelle achieved strong results. They saw an increase of 39 points in ad recall, as well as an increase of 4 points in association with the overall message. And most importantly, the campaign has a strong influence on hard-to-reach target audiences, encouraging an increase of 5 points in association with messages among millennials (Instagram website, 2019).

At present, SME businesses in Indonesia have used Instagram stories advertisements as their promotional media, due to their comprehensive features and having a clear target market, millennial generation. The millennial generation itself, according to Saratovsky \& Feldman (2013), has the characteristics of being, often online, creative, solution-centered, self-organized, open, and transparent. To prove the phenomenon of how millennial generation activities on social media Instagram, an initial survey was conducted with 30 respondents born in 1984-1998 in Denpasar and Badung City. The results of this survey stated that $100 \%$ of respondents had seen advertisements on Instagram stories, and $80 \%$ of respondents used Instagram more than 20 times a week. Based on the type of advertisement, respondents stated $93.3 \%$ often see Instagram Stories ads compared to other types of advertisements. This result can be stated that the millennial community in the city of Denpasar and Badung have seen advertisements on Instagram, especially on Instagram stories, so that business people must know how to attract attention and cause a positive attitude from consumers.

By utilizing advertisements on Instagram Stories, businesses should be able to reach a broader market. That makes advertisers must be able to create advertisements that can positively influence consumer attitudes because consumers can determine what Instagram ads are like and how much they want to get. Attitude is the last step before behavior; in other words, attitude will affect individual behavior and also consumer behavior (Aktan et al., 2016). In his research on attitudes towards website advertising, Aktan et al. (2016) said that if someone has a good attitude towards a brand, the posibility of this person buying the brand will be high. Therefore it is crucial to examine the attitude and uncover the factors that influence it.

The purpose of this study is to identify how Millenials consumer attitudes towards advertising on Instagram stories. Attitude is an evaluation of an object, ranging from the very negative to the very positive (Wood, 2000). Based on the general understanding of this attitude, it can be said that the attitude towards Instagram advertising is a consumer evaluation of Instagram advertising either negatively or positively.

Murillo (2017) examines how millennial attitudes in Mexico towards mobile search advertising. Murillo (2017) found that advertising value has a positive effect on Millenials' consumer attitudes in Mexico using mobile search advertising. Manel Hamouda (2018) examines how the influence of advertising value on consumer attitudes and responses, which shows the results of a positive correlation between advertising value and consumer attitudes on Facebook social media. Murat Aktan et al. (2016) also researched the effect of advertising value on consumer attitudes on website advertising. So it appears that there is a gap that needs to be done more research on consumer attitudes towards advertising on social media Instagram as the most widely used social media by Millenials.

According to Ducoffe (1995), advertising value is a subjective evaluation of an advertisement by a customer that determines the weight and value of the advertisement. Ducoffe (1996) proposes informativeness, entertainment, and irritation as antecedents of 
advertising value, which has a positive relationship with attitudes toward web advertising. Brackett and Carr (2001) proposed credibility as the fourth predictor of website advertising value and found a direct effect between three antecedents on attitudes toward website advertising. The main purpose of this research is to identify how advertising value affects the attitudes of millennial consumers in Denpasar and Badung towards Instagram Stories ads.

\section{MATERIALS AND METHODS OF RESEARCH}

The effectiveness of using online advertising is not easy, because we need to consider some essential factors to enhance the value of advertising. The concept of advertising value is defined as consumers' perception of utility and the relative value of advertising (Ducoffe, 1996). The advertising value model is the theory most widely used to explain user perceptions and attitudes towards advertising. Ducoffe (1996) states to use advertising through web effectively, the important thing is understand the attitude of the target audience, because this will affect their attitude towards an advertisement. However, understanding the attitude of the target audience is not enough. After this step, the most relevant online advertisement must be designed. At this stage, increasing the value of advertising becomes an essential issue because it plays a vital role in the effectiveness of web advertising and targets the viewer's attitude towards advertising. In increasing the value of advertising, the following four antecedent factors must be increased, namely entertainment, informativeness, irritation, and credibility.

Because consumers are exposed to hundreds of information every day on social media, it is hard to attract their attention. In order for advertising messages to quickly capture the attention of consumers, it is important to make it brief and entertaining (Zia, 2009; Katterbach, 2002). According to Alwitt et al. (1993), the consumers prefer to see advertisements that have more elements of entertainment and pleasure. Online messages that are highly enriched with entertaining content achieve a more positive assessment by the recipient and lead to higher targets to revisit the homepage than online messages without entertainment (Raney et al., 2003).

The entertainment value of advertising involves the experience of consumers' pleasure when exposed to the advertisement (Korgaonkar et al. 2001; Wang and Sun, 2010) and is an emotionally salient element that engages consumers with marketing messages thereby affecting the effectiveness of advertisements (Wang and Sun, 2010).

According to Ducoffe (1996) and Rubin (2002), informativeness is the ability of advertisements to deliver information to targeted audience effectively. According to Ducoffe (1996) and Rubin (2002), the informativeness of advertising can be considered an essential predictor of advertising value and is very important for ad effectiveness. Several similar studies share a similar perspective. For instance, in a study by Schlosser, it was shown that people's attitudes toward online advertising are influenced by informativeness and entertainment (Schlosser et al., 1999). In other studies, information from an advertisement was found to be one of the most critical determinants of ad values and attitudes towards advertising (Haghirian et al., 2005; Petrovici et al., 2007). According to Tsang et al., (2004), information from an advertisement has a positive relationship with the overall attitude of consumers towards advertising. Wang et al. (2009) examined the beliefs and attitudes of Chinese consumers towards online advertising and found that information was the most significant predictor of advertising values and attitudes.

According to Aaker et al. (1985), irritation is an advertisement that results in discomfort, intolerance, and unpleasant content. In this situation, consumers usually feel unhappy and respond negatively to advertisements like this. Therefore, whenever an advertisement gives a disturbing, attacking, manipulative message, consumers will have the perception that the advertisement is undesirable or irritating (Ducoffe, 1996).

Several researches have found that irritation negatively influences the effectiveness of an online advertisement and consumer attitudes towards online advertisement (Further et al., 2009; Hanghirian, 2005; Xu, 2007; Chakrabarty et al., 2005; Tsang et al., 2004). 
MacKenzie et al. (1989) define ad's credibility as audiences' perceptions of honesty, reliability, trust, and confidence in advertising. Lafferty et al. (1999) agree that advertising credibility is an important factor influencing consumer attitudes and behavior.

The credibility of advertising has a relationship with consumers' perceptions of truth and trust that directly affect the effectiveness of advertising. Online advertising allows us to create our advertisements, and there are no regulations regarding this. This situation can indicate that online advertising has lower credibility than other media (Prendergast et al., 2009).

According to Awalina (2017), attitude is a characteristic to respond positively or negatively to a behavior. Beliefs determine attitudes toward behavior about the consequences of a behavior, called behavioral beliefs. Attitudes can also be based on emotions and mean that someone can form positive feelings about information, products, or actions on the desired basis. Thus, attitudes can affect a person's behavior, feelings, and perception. Based on the literature review, a research conceptual framework can be drawn up as shown in Figure 1 and the operational definitions of each variable can be explained as Table 1.

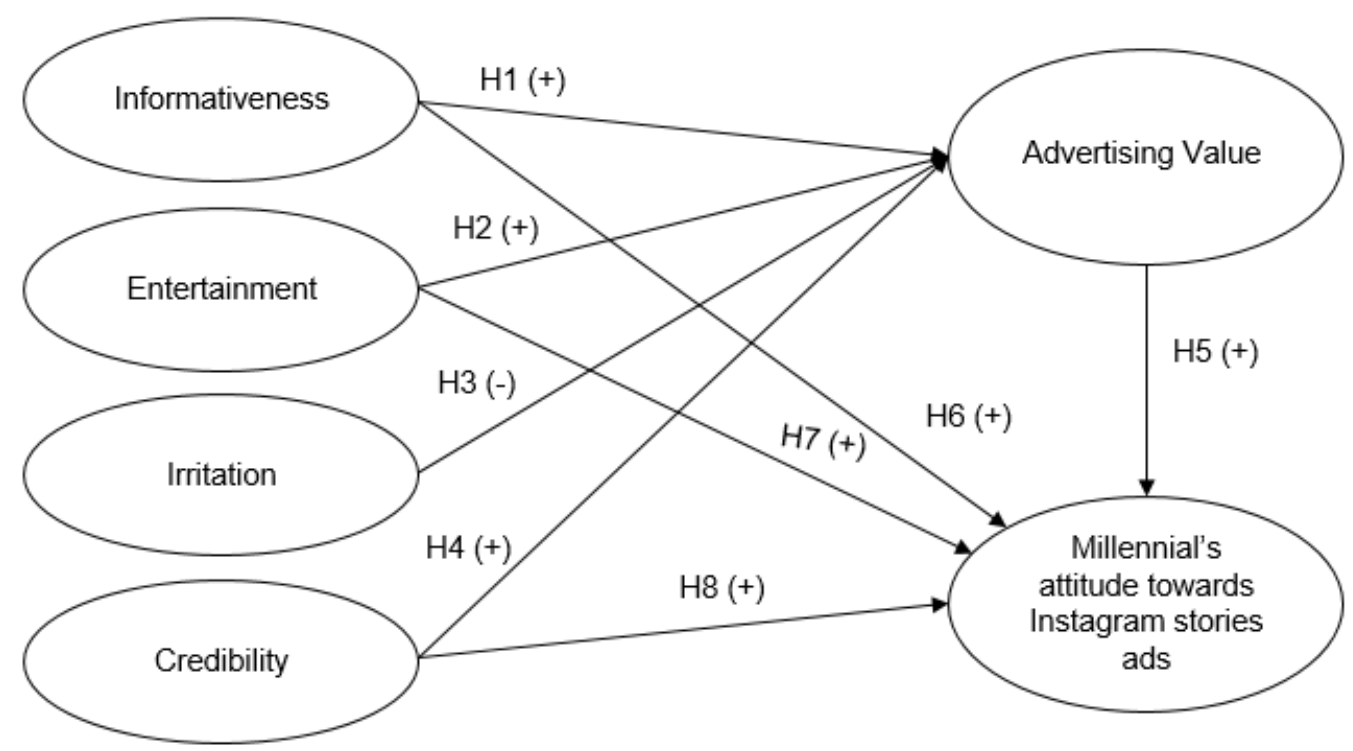

Figure 1 - Conceptual Framework

As the research conceptual framework, the hypotheses of this study are:

$\mathrm{H} 1$ : Informativeness of advertisements on Instagram stories has a positive effect on advertising value.

$\mathrm{H} 2$ : Entertainment of advertisements on Instagram stories have a positive effect on advertising value.

H3: Irritation of advertisements on Instagram stories have a negative effect on advertising value.

H4: Credibility of advertisements on Instagram stories have a positive effect on advertising value.

H5: Advertising value on Instagram stories has a positive effect on Millenials' consumer attitudes towards advertisement on Instagram stories.

H6: Informativeness on Instagram stories has a positive effect on Millenials' consumer attitudes towards advertisement on Instagram stories.

H7: Entertainment on Instagram stories has a positive effect on Millenials' consumer attitudes towards advertisement on Instagram stories.

H8: Credibility on Instagram stories has a positive effect on Millenials' consumer attitudes towards advertisement on Instagram stories. 
Table 1 - Variable, Dimension, and Research of Indicator

\begin{tabular}{|c|c|c|c|}
\hline $\begin{array}{l}\text { Type of } \\
\text { Variable }\end{array}$ & Variable & Indicator & References \\
\hline \multirow[t]{4}{*}{ Exogenous } & Informativenesss & $\begin{array}{l}\text { (X1.1) is a good source of product information } \\
\text { (X1.2) supplies relevant product/service } \\
\text { information } \\
\text { (X1.3) provides timely information }\end{array}$ & $\begin{array}{l}\text { Murillo et al. (2016), } \\
\text { Aktan et al. (2016) } \\
\text { Ducoffe (1996), Cadet et } \\
\text { al. (2017) and Logan } \\
(2012)\end{array}$ \\
\hline & Entertainment & $\begin{array}{l}\text { (X2.1) is entertaining } \\
(X 2.2) \text { is enjoyable } \\
(X 2.3) \text { is fun to use }\end{array}$ & $\begin{array}{l}\text { Murillo et al. (2016), } \\
\text { Tsang et al. (2004), } \\
\text { Aktan et al. (2016), } \\
\text { Cadet et al. (2017), } \\
\text { Logan (2012) and } \\
\text { Ducoffe (1996) }\end{array}$ \\
\hline & Irritation & $\begin{array}{l}\text { X3.1) is irritating } \\
\text { (X3.2) is too much advertising } \\
\text { (X3.3) is insult people's intelligence }\end{array}$ & $\begin{array}{l}\text { Murillo et al. (2016) and } \\
\text { Ducoffe (1996), Unal et } \\
\text { al (2011) }\end{array}$ \\
\hline & Credibility & $\begin{array}{l}(X 4.1) \text { is trustworthy } \\
(X 4.2) \text { is believable } \\
(X 4.3) \text { is convincing }\end{array}$ & $\begin{array}{l}\text { Murillo et al. (2016), } \\
\text { Tsang et al. (2004), } \\
\text { Aktan et al. (2016), } \\
\text { Cadet et al. (2017), } \\
\text { Logan (2012) }\end{array}$ \\
\hline \multirow[t]{2}{*}{ Endogenous } & $\begin{array}{l}\text { Advertising } \\
\text { value }\end{array}$ & $\begin{array}{l}(\mathrm{Y} 1.1) \text { is useful } \\
(\mathrm{Y} 1.2) \text { is valuable } \\
(\mathrm{Y} 1.3) \text { is important }\end{array}$ & $\begin{array}{l}\text { Murillo et al. (2016), } \\
\text { Cadet et al. (2017); } \\
\text { Logan (2012); Ducoffe } \\
\text { (1996) }\end{array}$ \\
\hline & $\begin{array}{l}\text { Customer } \\
\text { Attitude }\end{array}$ & $\begin{array}{l}\text { (Y2.1) helps me to find products/services that } \\
\text { match my personality and interests } \\
\text { (Y2.2) helps me know which brands have the } \\
\text { features I am looking for } \\
\text { (Y2.3) willing to engage with the advertising } \\
\text { (Y2.4) is a good way to learn about what } \\
\text { products/services are available } \\
\text { Y2.5) willing to receive the advertising in the } \\
\text { future }\end{array}$ & $\begin{array}{l}\text { Jimenez dan San-Martin } \\
\text { (2017) }\end{array}$ \\
\hline
\end{tabular}

The population in this study is that everyone who lives in Denpasar and Badung, has an Instagram account, and was born in 1984-1998 is the population in this study, so the total population cannot be determined with certainty (infinite). Consideration of the number of samples is based on Hair et al., (2014) which states that the sample size for the Partial Least Square (PLS) method ranges from 30-100 samples. The research sample was determined using non-probability sampling techniques (Sugiyono, 2016: 124). Roscoe in Sugiyono (2016: 133) recommends that the ideal sample size for multivariate analysis should be 5 to 10 times the total indicator. So with a total number of indicators of 20, a minimum of 100 respondents is needed in this study. Data will be analyzed by Structural Equation Modeling (SEM) analysis (Ferdinand, 2014: 173).

This research use Google Forms to conduct the online survey, which already responsive with the resolution in both desktop and smartphone. We reasoned many respondents would first see the invitation to complete the survey in their mobile phone, and we wanted to make it easy for them to respond to the online survey from their mobile phone.

The research instrument used for data collection in the form of a questionnaire that uses a Likert scale ( 5 points), and has been tested for validity and reliability. In this case, the assumption is that the Likert scale produces measurements of variables on the interval scale (Rahyuda, 2016). The collected data was analyzed by descriptive analysis techniques and analysis of SEM (Structural Equation Model) with Smart PLS software.

\section{RESULTS AND DISCUSSION}

This study also briefly describes the characteristics of the research respondents, namely millennials in Denpasar and Badung. The characteristics of the respondents are: 
(1) gender; (2) age; (3) formal education level; (4) employment; and (5) length of time using Instagra. The characteristics of the research respondents were described by presenting characteristics based on demographic characteristics such as gender, age, education level, employment and length of time using Instagram. Data were obtained through questionnaire survey techniques that were collected by the researcher. The profile of the respondents is presented in detail in Table 2.

Table 2 - Characteristics of respondents

\begin{tabular}{|c|c|c|c|}
\hline \multicolumn{2}{|c|}{ Characteristics } & Total & Percentages \\
\hline \multirow[t]{2}{*}{ Gender } & Male & 55 & $55 \%$ \\
\hline & Female & 45 & $44 \%$ \\
\hline \multirow[t]{3}{*}{ Age (year) } & 21-25 & 33 & $33 \%$ \\
\hline & $26-30$ & 49 & $49 \%$ \\
\hline & $31-35$ & 18 & $18 \%$ \\
\hline \multirow[t]{4}{*}{ Education Level } & SMA & 23 & $23 \%$ \\
\hline & Diploma & 7 & $7 \%$ \\
\hline & Bachelor (S1) & 53 & $53 \%$ \\
\hline & Magister (S2) & 17 & $17 \%$ \\
\hline \multirow[t]{6}{*}{ Employment } & College student & 21 & $21 \%$ \\
\hline & Civil servants & 23 & $23 \%$ \\
\hline & Private employees & 38 & $38 \%$ \\
\hline & Businessman & 10 & $10 \%$ \\
\hline & Housewife & 1 & $1 \%$ \\
\hline & Does not working & 1 & $1 \%$ \\
\hline \multirow[t]{4}{*}{ Length of Instagram Usage } & $<1$ year & 1 & $1 \%$ \\
\hline & $1-<3$ years & 16 & $16 \%$ \\
\hline & $3-5$ years & 41 & $41 \%$ \\
\hline & $>5$ years & 42 & $42 \%$ \\
\hline
\end{tabular}

Table 3 - Indicator loadings, scale Cronbach alphas and Composite reliabilities

\begin{tabular}{|c|c|c|c|}
\hline Scale & Indicator Loading & Cronbach Alpha & Composite Reliability \\
\hline Informativeness & & 0.931 & 0.956 \\
\hline X1.1 & 0.958 & & \\
\hline X1.2 & 0.922 & & \\
\hline X1.3 & 0.933 & & \\
\hline Entertainment & & 0.931 & 0.956 \\
\hline X2.1 & 0.961 & & \\
\hline X2.2 & 0.904 & & \\
\hline$\times 2.3$ & 0.948 & & \\
\hline Irritation & & 0.897 & 0.936 \\
\hline X3.1 & 0.920 & & \\
\hline X3.2 & 0.909 & & \\
\hline X3.3 & 0.903 & & \\
\hline Credibility & & 0.907 & 0.941 \\
\hline X4.1 & 0.927 & & \\
\hline$X 4.2$ & 0.905 & & \\
\hline X4.3 & 0.922 & & \\
\hline Advertising value & & 0.904 & 0.940 \\
\hline Y1.1 & 0.937 & & \\
\hline Y1.2 & 0.884 & & \\
\hline Y1.3 & 0.928 & & \\
\hline Customer Attitude & & 0.949 & 0.961 \\
\hline Y2.1 & 0.914 & & \\
\hline Y2.2 & 0.895 & & \\
\hline Y2.3 & 0.918 & & \\
\hline Y2.4 & 0.879 & & \\
\hline Y2.5 & 0.954 & & \\
\hline
\end{tabular}

The results of descriptive statistical analysis showed that most of the respondents of millennials in Denpasar and Badung were between 26-30 years old, namely 49 people $(49 \%)$. Based on employment status, most of the respondents already working as a civil servants (23 people), private employee (38 people) and businessman (10 people). Furthermore, $83 \%$ of respondents have used Instagram more than 3 years with $42 \%$ respondents are using more than 5 years. This indicating millennial in Denpasar and Badung mostly have an Instagram account before Instagram launched their advertising features.

Partial Least Squares (PLS) method of structural equation modeling was used to test the hypothesized model, which is compatible for exploratory research and is not subject to 
the normality assumption of covariance based SEM (Hair, Sarstedt, Ringle, \& Mena, 2012). Estimation was executed using SmartPLS (Ringle, Wende, \& Will, 2005). We first evaluated the measurement or outer model, which involves examining indicator reliability, internal consistency reliability, convergent validity and discriminant validity (Hair et al., 2012).

Table 3 shows the outer loadings, Cronbach alphas and composite reliabilities. All twenty indicators have a value above the required outer loading minimum value of 0.60 (Latan and Ghozali, 2014). In addition, composite reliabilities for all scales are well above the suggested threshold of 0.70 (Bagozzi \& Yi, 1988), the results indicating good internal consistency.

Table 4 provides the average variance extracted (AVE), square root of the AVE and inter-construct correlations. All AVE values in Table 4 are above 0.50 which indicates the indicators have good convergent validity (Bagozzi \& Yi, 1988). Furthermore, obey with the Fornell-Larcker criterion; each of the elements on the main diagonal in Table 4 is higher than the respective row and column off-diagonal elements, which indicates adequate discriminant validity at the construct level (Henseler, Ringle, \& Sinkovics, 2009; Hulland, 1999).

Table 4 - Average variance extracted and inter-construct correlations

\begin{tabular}{|c|c|c|c|c|c|c|c|}
\hline & AVE & Inform & Entert & Irrit & Credib & Advalue & Attitude \\
\hline Inform & 0.879 & 0.938 & & & & & \\
\hline Entert & 0.880 & 0.767 & 0.938 & & & & \\
\hline Irrit & 0.829 & -0.757 & -0.840 & 0.911 & & & \\
\hline Credib & 0.843 & 0.813 & -0.818 & -0.818 & 0.918 & & \\
\hline Advalue & 0.840 & 0.813 & 0.856 & -0.840 & 0.861 & 0.916 & \\
\hline Attitude & 0.832 & 0.820 & 0.845 & -0.849 & 0.862 & 0.897 & 0.912 \\
\hline
\end{tabular}

The cross loadings of the indicators in this research show a supportive check for discriminant validity, at the indicator level (Henseler et al., 2009). The loading value of each indicator in Table 4 should be higher than all of its cross-loadings. Overall, the measurement model in Table 4 displays acceptable indicator and internal consistency reliability, as well as convergent and discriminant validity.

After the estimated model meets the criteria of the outer model, then the structural model is tested. Structural model analysis is performed using the R-square test, which is a goodness-fit model test.

Table 5 - R-square endogenous latent variables

\begin{tabular}{ll}
\hline Variable & R-square \\
\hline Advertising value & 0.832 \\
Customer Attitude Toward Instagram Ads & 0.851 \\
\hline
\end{tabular}

Based on the results in Table 5, it can be explained that the R-square value for the Advertising value is 0.832 , meaning the influence of variables of entertainment, informativeness, irritation and credibility on advertising value is $83.2 \%$ and the remaining $16.8 \%$ is influenced by other variables outside the model. The R-square value for millennial customer attitude toward Instagram Stories ads variable is 0.851 which means the influence of entertainment, informativeness, credibility and advertising value on millennial customer attitude is $85.1 \%$ and the remaining $14.9 \%$ is influenced by other variables outside the model. Furthermore, based on $\mathrm{R}^{2}$ in Table $4, \mathrm{Q}^{2}$ or Stone Geiser Q-Square tests can be calculated, namely: $Q^{2}=1-\{(1-0.832)(1-0.851)\}=1-\{(0.168)(0.149)\}=0.975$. The calculation results obtained a $Q^{2}$ value of $0.975>0$. Therefore, it can be said that the model has good predictive relevance. This means that $97.5 \%$ of the variation in millennial customer attitude toward ads variables can be explained by variables of entertainment, informativeness, credibility and advertising value, while the rest are explained by other variables outside the model.

The bootstrap method is used to test the significance of the main effects and mediation in the $\mathrm{H} 1$ to $\mathrm{H} 8$ hypothesis. In each path the influence of exogenous variables on endogenous variables is tested by using the t test (T-test) and $p$-value, where $p$-value is compared with a (5 percent). The overall path analysis calculation results can be seen in the 
path coefficient, the value of T-test and $p$ value. If the $p$-value is smaller than 0.05 , then the effect is declared significant, and vice versa.

Table 6 - Path Coefficients

\begin{tabular}{|c|c|c|c|c|c|}
\hline & $\begin{array}{l}\text { Original Sample } \\
\text { (O) }\end{array}$ & $\begin{array}{l}\text { Sample Mean } \\
\text { (M) }\end{array}$ & $\begin{array}{c}\text { Standard Deviation } \\
\text { (STDEV) }\end{array}$ & $\begin{array}{l}\text { T Statistics } \\
(\mid \mathrm{O} / \text { STDEV } \mid)\end{array}$ & $\begin{array}{c}\mathrm{P} \\
\text { Values }\end{array}$ \\
\hline Advertising value -> Attitude & 0.441 & 0.448 & 0.068 & 6.472 & 0.000 \\
\hline Credibilty $->$ Advertising value & 0.284 & 0.289 & 0.107 & 2.645 & 0.008 \\
\hline Credibilty -> Attitude & 0.213 & 0.210 & 0.074 & 2.883 & 0.004 \\
\hline $\begin{array}{l}\text { Entertainment -> Advertising } \\
\text { value }\end{array}$ & 0.275 & 0.275 & 0.093 & 2.944 & 0.003 \\
\hline Entertainment -> Attitude & 0.164 & 0.159 & 0.051 & 3.185 & 0.002 \\
\hline $\begin{array}{l}\text { Informativeness -> } \\
\text { Advertising value }\end{array}$ & 0.201 & 0.193 & 0.079 & 2.528 & 0.012 \\
\hline Informativeness -> Attitude & 0.163 & 0.164 & 0.079 & 2.060 & 0.040 \\
\hline Irritation -> Advertising value & -0.225 & -0.229 & 0.085 & 2.650 & 0.008 \\
\hline
\end{tabular}

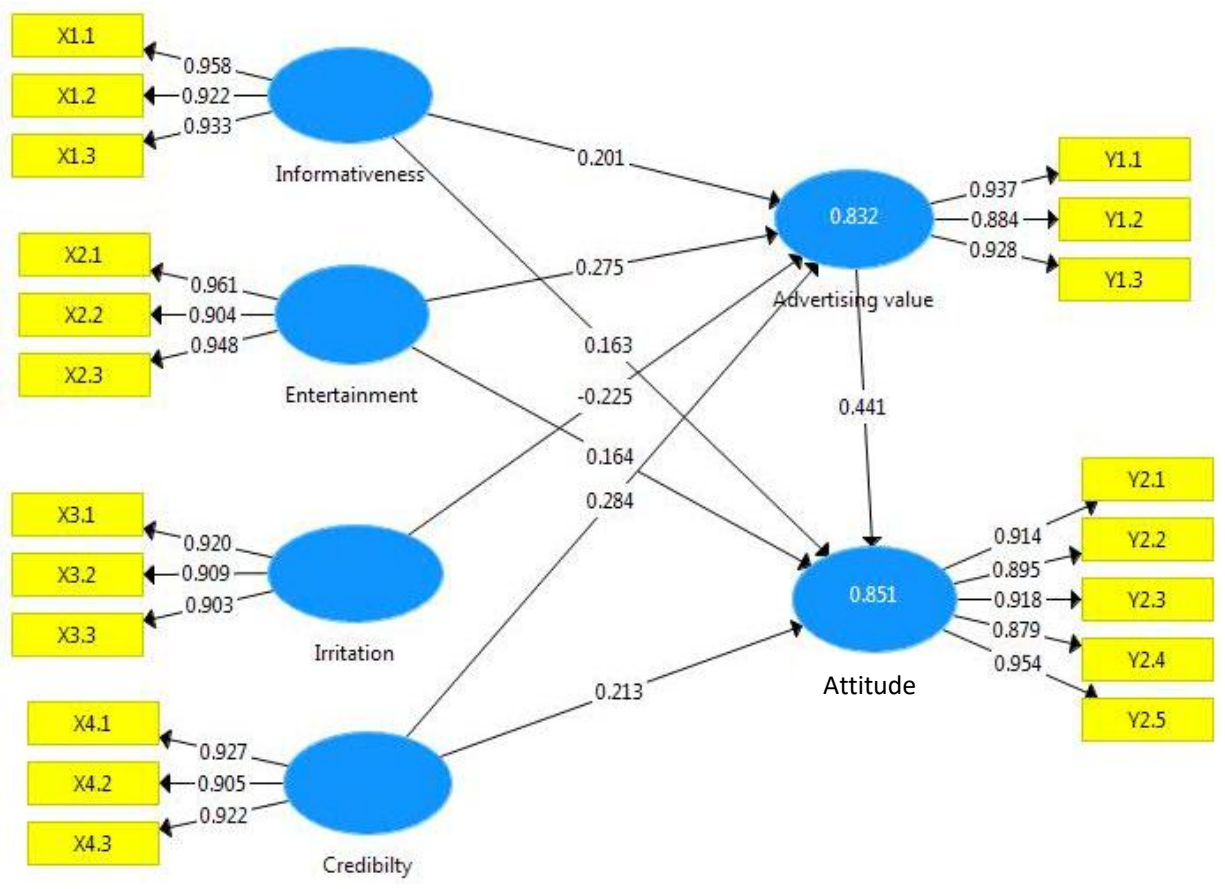

Figure 2 - Full Model Partial Least Square

Table 7 - Summary of Research Hypotheses

\begin{tabular}{ll}
\hline Hypothesis & Model Conclusion \\
\hline H1 - Informativeness on AdValue (+) & Supported \\
H2 - Entertainment on Advalue $(+)$ & Supported \\
H3 - Irritation on Advalue $(-)$ & Supported \\
H4 - Credibility on Advalue $(+)$ & Supported \\
H5 - AdValue on Attitude $(+)$ & Supported \\
H6 - Informativeness on Attitude $(+)$ & Supported \\
H7 - Entertainment on Attitude $(+)$ & Supported \\
H8 - Credibilyty on Attitude $(+)$ & Supported \\
\hline
\end{tabular}

Results as presented in Table 7 show that all of the hypothesized models are supported and have significant effect with a statistical t value more than 1.96 and $p$ values less than 0.05 . All of the variables have positive effect, but irritation is the only variable that has negative effect on advertising value.

\section{CONCLUSION}

Using a sample of Millennials in Denpasar and Badung, this study extends to the previous research on millennials user attitudes toward Twitter ads (Murillo et al., 2016). The 
survey shows that $83 \%$ of the respondents have been using Instagram more than 3 years and all of the respondents actively see the Instagram stories ads on their Instagram account.

The study also surveyed users who in the past had engaged on Instagram stories ads to determine how they formed their assessments of the advertising value of these ads, as well as their general attitude toward Instagram stories ads. We found a positive significant effect of informativeness on perceived advertising value. We conclude that millennial users of Instagram are interested above all in the informative quality of the ads they see on their stories. Moreover, informativeness also had a direct effect on attitude toward Instagram stories ads. The practical implication for advertisers is that providing relevant and timely product/service information in stories ad visual leads to a higher advertising value assessment from users and a more positive attitude toward this type of ads.

Entertainment also had a strong effect on Millennials' assessment of advertising value. This reflects Instagram users' cognitive assessment of Instagram stories ads' entertainment quality, which is an interesting result considering the ads themselves are images or video with just 15 seconds duration. As regards the hypothesized direct effect between entertainment and attitude, the link was substantial and statistically significant among the respondents. The implication for advertisers is that despite the duration of the stories ads just 15 seconds, the millennial respondents can and do evaluate them as entertaining and contributing to the ad's perceived value. Therefore developing witty or humorous image or video will positively impact advertising value for all audiences, as well as attitude toward Instagram stories ads.

Irritation had a significant negative effect on perceived advertising value of the respondents. The implication is that advertisers should try to avoid tactics that users find annoying, such as incongruencies between the visual and the information on the landing page.

Compared to informativeness and entertainment, credibility had the strongest positive impact on user assessments of advertising value in the full sample. Furthermore, there remained a significant direct effect on attitude. These findings consistent with previous research on desktop sponsored results, where credibility had the largest impact on advertising value (Lin and Hung, 2009). But the results show a contrast with previous research regarding attitudes toward mobile search ads among Mexican millennials that conducted by Murillo, 2016. The reason of this contrast is because the sample on that research is probably less sensitive to the credibility of the ads, because they excluded respondents who reported never clicking on search ads, presumably due to credibility concerns. The practical implication for advertisers is that developing visual that enhances the credibility of the ad (e.g. clarity image and message) will at least impact general attitude toward Instagram stories ads.

The findings of this study come at a very good time. The sample of the millennial generation that was investigated in the current study spent approximately 4 hours and 11 minutes on their different social media platforms daily, they are mostly using Instagram (Bowles et.al., 2018), and smartphone penetration is also growing rapidly (Emarketer, 2014). This means advertisers, especially local merchants, will have plentiful opportunities to connect with potential millennial customers, who are increasingly spending time on Instagram.

The findings of this study also accordance with the Facebook's study in Indonesian Instagram user behavior. The important factors of people in Indonesia watch Instagram stories are authenticity of the content and funny of the content (Facebookm 2018). Furthermore, the Indonesian user usually find information mostly in Instagram feed instead of Instagram stories.

Social media ads, such as Instagram ads, give the advertiser a number of personalization options that can enhance an ad for a particular user. Because this company constantly monitor their user behavior to give precise information to the advertiser. Geographical location, gender, approximate age and broad interests are usually revealed as well. Hence, advertisers can craft a highly personalized ad visual to be displayed to users that trigger any of these characteristics. For instance, a local Japanese restaurant can create 
an ad with a special promotion to be displayed only to users who have interest on Japanese food within a three mile radius of the restaurant. This enables small businesses to leverage their location, using a sophisticated and cost-efficient advertising medium with a high probability of success.

To summarize, the following actionable recommendations for advertisers are warranted by study results: if not already doing so, start using Instagram stories ads; leverage store location by using personalized image, video and ad copy to connect with consumers nearby; fine-tune the ads visual with respect to informativeness, entertainment, irritation and credibility, using the suggestions given before.

This research relied on the millennial sample, where we expected high social media and smartphone penetration. This sample is not different in substantive ways from international samples of Millennial smartphone owners. Various authors have pointed to a global convergence of attitudes and behavior within the Millennial age group because of the internet and the globalization of communication it made possible (Meredith et al. 2002; Moore, 2012; Razorfish, 2015).

To simplify the survey we only asked respondents about their experience with the Instagram stories ads, which at the time according to VidMob's 2018 "State of Social Video" report, $60 \%$ of Millennials use Insta Stories. However, we should point out that the Facebook Ads platform offers similar stories feature with personalization ad targeting capabilities (Facebook, 2018). The guidelines we gave before are also valid for Facebook stories ads, and if marketing budget is available, we would recommend local merchants to advertise in both platforms to extend their reach.

Expanding the sample beyond the young adult demographic is important direction for future studies. Although Millennials are generally regarded as more techno-savvy than their parents, smartphone penetration is rapidly growing among elderly people. A recent study showed that $69 \%$ of US senior citizens use their smartphone at least sometimes when shopping in-store (Norton, 2014).

We also recommend to expand the research location to other areas in Indonesia or even develop the samples to other countries in South East Asia. The fact that the survey can be delivered through online platform such as Google Forms, in both desktop and smartphone screen resolutions makes such studies fairly quick and straightforward, and research on user perceptions of social media advertising (Facebook, Instagram, Twitter, Linkedin, Pinterest) is still growing.

\section{REFERENCES}

1. Aktan, M., Aydogan, S., Aysuna, C., \& Cad, M. Z. (2016). Web advertising value and students'attitudetowards web advertising. European Journal ofBusiness and Management, 8(9), 86-97.

2. Alwitt, L. F., \& Berger, I. E. (1993). Understanding the Link between Environmental Attitudes and Consumer Product Usage: Measuring The Moderating Role Of Attitude Strength. Advances in Consumer Research, 20, 189-194.

3. Brackett, L. K., \& Carr, B. N. (2001). Cyberspace Advertising vs. Other Media: Consumer vs. Mature Student Attitudes. Journal of Advertising Research, 22-23.

4. Ducoffe, R. H. (1995). How Consumers Assess the Value of Advertising. Journal of Current Issues \& Research in Advertising, 17(1), 1-18.

5. Ducoffe, R. H. (1996). Advertising value and advertising on the Web. Journal of Advertising Research, 36(5), 21-35.

6. El-Haddadeh, R., Weerakkody, V., \& Peng, J. (2012). Social networking services adoption in corporate communication: the case of China. Journal of Enterprise Information Management, 25, 559-575.

7. Ghozali, I., \& Latan, H. (2014). Partial Least Squares Konsep, Metode dan Aplikasi Menggunakan Program WARPPLS 4.0. Semarang: Badan Penerbit Universitas Diponegoro. 
8. Haghirian, P., \& Madlberger, M. (2005). Consumer Attitude toward Advertising via Mobile Devices - An Empirical Investigation among Austrian Users. Proceedings of the 13th European Conference on Information Systems.

9. Hair, J. F., Sarstedt, M., Pieper, T., \& Ringle, C. M. (2012). The Use of Partial Least Squares Structural Equation Modeling in Strategic Management Research: A Review of Past Practices and Recommendations for Future Applications. Long Range Planning, 45(5-6), 320-340.

10. Hamouda, M. (2018). Understanding social media advertising effect on consumers' responses: An empirical investigation of tourism advertising on Facebook. Journal of Enterprise Information Management, 31(3), 426-445.

11. Haq, Z. U. (2009). E-mail advertising: A study of consumer attitude toward e-mail advertising among Indian users. Journal of Retail and Leisure Property, 8(3).

12. Instagram. (2019, August 5). Bangun Bisnis Anda di Instagram. Retrieved from Instagram: https://business.instagram.com/advertising/

13. Korgaonkar, P., Silverblatt, R., \& O'Leary, B. (2001). Web advertising and Hispanics. Journal of Consumer Marketing, 18(2), 134-152.

14. Larose, R., Mastro, D., \& Eastin, M. S. (2001). Understanding Internet Usage: A SocialCognitive Approach to Uses and Gratifications. Social Science Computer Review, 19(4), 395-413.

15. MacKenzie, S. B., \& Lutz, R. J. (1989). An Empirical Examination of the Structural Antecedents of Attitude Toward the Ad in an Advertising Pretesting Context. Journal of Marketing, 53(2), 48-65.

16. Murillo, E. (2017). Attitudes toward mobile search ads: a study among Mexican millennials. Journal of Research in Interactive Marketing, 11(1), 91-108.

17. Norton, N. (2014). Survey: older generations embrace mobile as local shopping companion. Retrieved from Search Engine Land: http://searchengineland.com/surveyolder-generations-embrace-mobile-local-shopping-companion-188870

18. Petrovici, D., \& Paliwoda, S. (2007). An empirical examination of public attitudes towards advertising in a transitional economy. International Journal of Advertising, 26(2), 247-276.

19. Prendergast, M. L. (2009). Interventions to Promote Successful Re-Entry Among DrugAbusing Parolees. Addict Sci Clin Pract., 5(1), 4-13.

20. Raacke, J., \& Bonds-Raacke, J. (2008). MySpace and Facebook: Applying the Uses and Gratifications Theory to Exploring Friend-Networking Sites. Cyberpsychology \& Behavior, 11, 169-174.

21. Rahyuda, K. (2016). Metode Penelitian Bisnis. Denpasar: Udayana University Press.

22. Raney, A. A., Arpan, L., Brill, D., \& Pashupati, K. (2003). At the Movies, on the Web: An Investigation of the Effects of Entertaining and Interactive Web Content on Site and Brand Evaluations. Journal of Interactive Marketing, 17(4), 38-53.

23. Rubin, A. (2002). The uses-and-gratifications perspective of media effects. Bryant, J. and Zillmann, D. (Eds), Media Effects: Advances in Theory and Research, 525-48.

24. Saratovsky, K. D., Feldmann, D., \& Case, J. (2013). Cause for Change: The Why and How of Nonprofit Millennial Engagement. New Jersey: John Wiley \& Sons.

25. Schlosser, A., Shavitt, S., \& Kanfer, A. (1999). Survey of Internet users attitudes toward Internet advertising. Journal of Interactive Marketing, 13(3), 34-54.

26. Science, S. D. (2018, June 21). How Do People Perceive and Use Instagram Stories and Feed? Retrieved from Facebook For Business: https://www.facebook.com/

27. Statista. (2020, February 15). Leading countries based on number of Instagram users as of January 2020. Retrieved from Statista: https://www.statista.com/

28. Sugiyono. (2016). Metode Penelitian Kuantitatif, Kualitatif dan R\&D. In Sugiyono, Metode Penelitian Kuantitatif, Kualitatif dan R\&D (pp. 124, 133). Bandung: PT Alfabet.

29. Tsang, M. M. et al (2004). Consumer Attitudes toward Mobile Advertising: An Empirical Study. International Journal of Electronic Commerce, 8(3), 65-78.

30. Wood, W. (2000). Attitude Change: Persuasion and Social Influence. Annual Review of Psychology, 51, 539-570. 